\title{
INVESTIGATION OF KITCHEN STORAGE OF HOSPITALITY FACILITIES
}

\author{
Ayşe Nur Songür ${ }^{15}$ \\ Eren Canbolat ${ }^{16}$ \\ Funda Pınar Çakıroğlu ${ }^{17}$
}

\begin{abstract}
Food and beverage service in the hospitality facilities is not for meeting only one physiological requirement for the guests. Preparing food and drink with good quality materials in accordance with hygiene regulations and offering them nicely ties the guests more to operation. Safe food production and services can be performed in a healthy way by providing some conditions. Storage of food in suitable conditions is one of the important steps in the food safety chain. In this study, it is aimed to examine kitchen storage of hospitality facilities in Ankara. For this reason, seven different hospitality facilities in Ankara were visited, kitchen storages were examined and storage conditions were evaluated by taking photographs. At the end of the study, the following results were observed: The shelves used in storage were not properly placed, the materials on the shelves are irregularly placed, the air conditioners were not maintained and the ventilation system was not working well, there was no system in storage and materials were hoarding, containers used were not suitable for storage,the foods stored were not covered, raw and cooked food was stored together, cleaning of the storages was not taken care of. As a consequence, it has been determined that the necessary technical and hygienic conditions to ensure the safe storage of food in the hospitality facilities are insufficient. Inadequacies of physical properties of storage areas and storage of foods as it will be leading to contamination are an important threat to safe food production. In order to be able to provide a safe food and beverage service in hospitality facilities, the necessary physical conditions of the stores, the proper storage of the food with hygienic rules should be ensured and supervised.
\end{abstract}

Key words: food storage, hospitality facility, food safety.

\section{INTRODUCTION}

Accommodation enterprises are the enterprises whose main function is to serve and provide services, especially the accommodation and catering services, to their guests. Therefore, the success of these enterprises is determined by the quality of the service they give. Most of the service provided to customers of accommodation enterprises is carried out by the catering division. To meet the nutritional needs of customers, supply them food and beverages, ensure them to rest and enjoy in the enterprise, show the necessary respect and service, make them satisfied for the social and psychological

\footnotetext{
${ }^{15}$ Research Assistant, Department of Nutrition and Dietetic, Institute of Health Sciences, Ankara University.

${ }^{16}$ Research Assistant, Department of Gastronomy and Culinary Arts, Faculty of Tourism, Ondokuz Mayıs University.

${ }^{17}$ Professor, Department of Nutrition and Dietetic, Faculty of Health Sciences, Ankara

University.
} 
aspects, and to improve the success of the enterprise are major tasks of the catering division (Erdoğan, 2002).

The guests who will stay in these enterprises want to be satisfied with the catering division first because catering section in the accommodation enterprises is the section where food and beverage need, which is one of the oldest and greatest pleasures of human-being, is met (Şimşek, 2006). Satisfaction with food and beverages is an important factor creating a destination loyalty of customers. The kitchens, where the food and beverage productions are performed, must have good and sufficient equipment in all respects to increase the profitability of the accommodation enterprises (Özmen, 1994).

The dishes prepared in the accommodation enterprises should not only be suitable only in terms of appearance, flavor or nutrition but also be safe. Food security in these enterprises is extremely important in terms of protecting the health of the customers. It is an obligation that hygienic regulations are adhered to during the purchase, storage, preparation, cooking, and serving the food to ensure food safety and prevent foodborne illnesses. Hygienic storage of the foods that have been purchased is important to prevent them from deterioration and being harmful to health. If the food is not stored in the proper conditions, it will quickly deteriorate, various nutrient loss will occur, and it may become health-threatening (Bulduk, 2003). As a result of any disease or poisoning in the customers caused by the non-hygienic condition of the food produced in the kitchen, there will be irreversible and unrecoverable consequences for the enterprise and its employees (Özdemir 2001).

In the light of the information in the literature, it is aimed to examine the kitchen storages and evaluate the general conditions of them in the accommodation enterprises.

\section{METHOD}

This study is observational and descriptive in nature and it was planned to include the accommodation enterprises in Ankara city center. According to the data of the Ministry of Culture and Tourism of the Republic of Turkey in 2016, there are a total of 201 accommodation enterprises in Ankara province; 26 with tourism investment license and 175 with tourism operation license and therefore, the sample of this study was composed of these 201 enterprises (http://yigm.kulturturizm.gov.tr/TR,9860/turizmbelgeli-tesisler.html). The sample size to be reached was calculated by the formula $\mathrm{n}=$ $\left(\mathrm{Nt}^{2} \mathrm{pq}\right) /\left(\mathrm{d}^{2}(\mathrm{~N}-1)+\mathrm{t}^{2} \mathrm{pq}\right)($ Saka, 2004). 90\% confidence coefficient and $20 \%$ error margin were taken into consideration in that formula. The rule of thumb applied in this type of sampling is $(p)=(q)=0.5$. In this case, a constant sampling error results in the largest possible sample volume (Malhotra, 1993). The sample size was calculated as 16 upon the application of the formula. Random sampling method was utilized in the selection of the sample, but only 7 accommodation enterprises agreed to participate in the study. Three of the accommodation enterprises that accepted to participate in the 
study are 4-star hotels and four of them are 5-star hotels. The kitchen storages of the visited hotels were examined, and hygiene assessments were made by taking photographs in the scope of this study.

\section{RESULTS}

The general problems observed in the kitchen storages of accommodation enterprises were also listed below with the photographs taken:

$>$ The shelves used in storage were not properly placed and the materials on the shelves are irregularly placed.

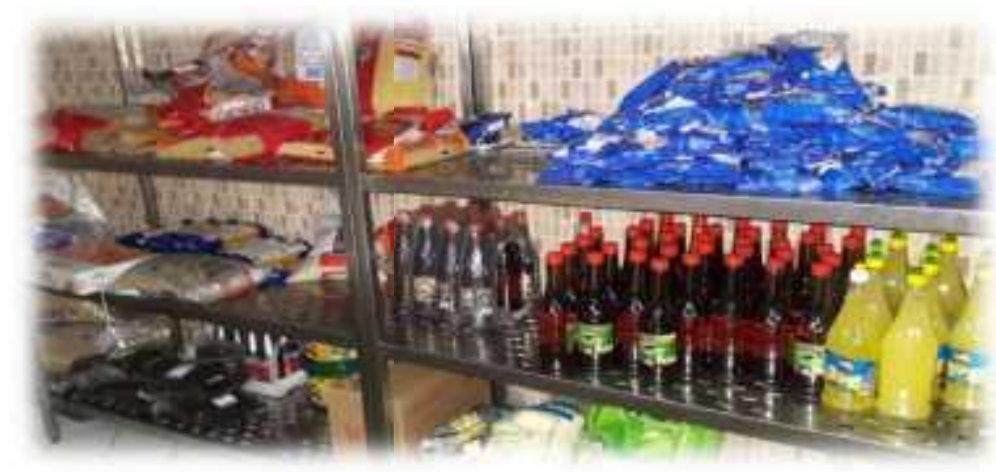

Fig. 1. The products are irregular and the open and closed packages were placed mixed.

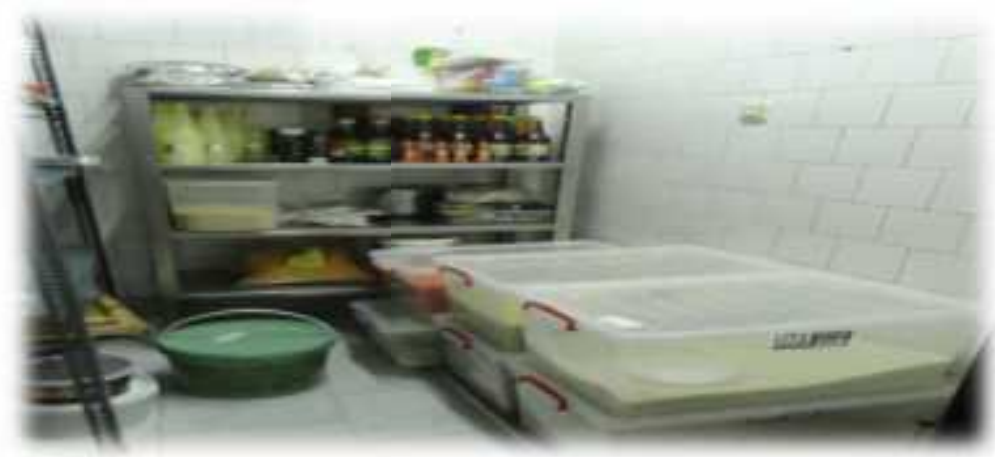

Fig. 2. This is a dry legumes store but empty shelves have been placed in different materials and created irregularities.

$>$ The air conditioners were not maintained and the ventilation system was not working well. 


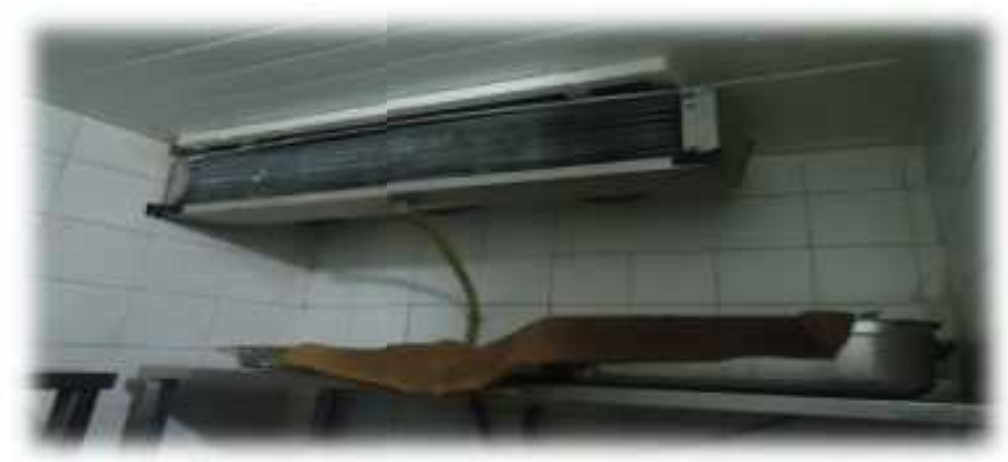

Fig 3. The air conditioning is old and maintenance-free.

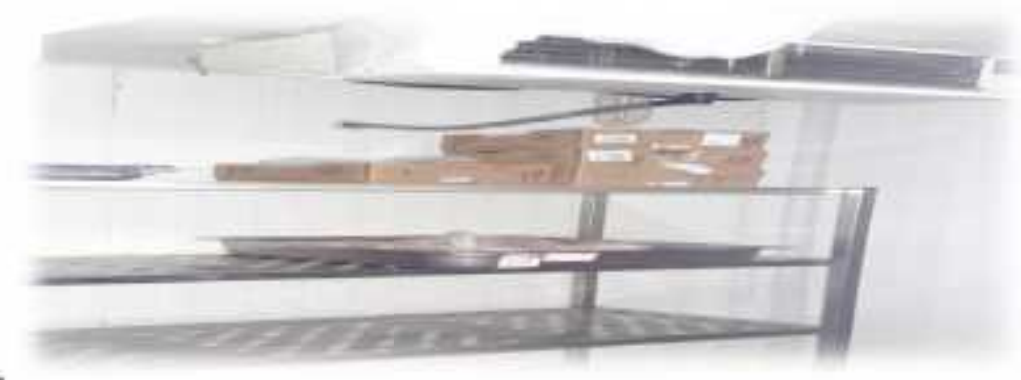

Fig. 4. The air conditioner be covered with ice because of extreme cooling.

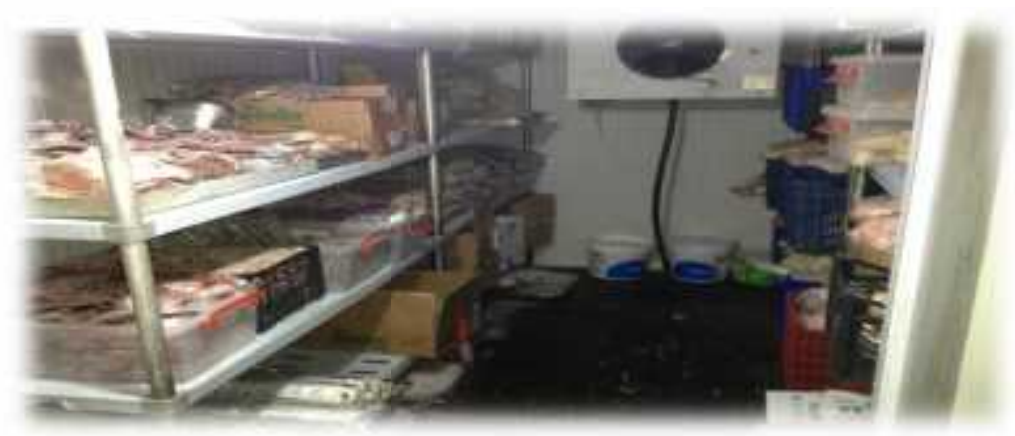

Fig. 5. The ventilation is maintenance-free, the meat was frozen.

$>$ There was no system in storage and materials were hoarding. 


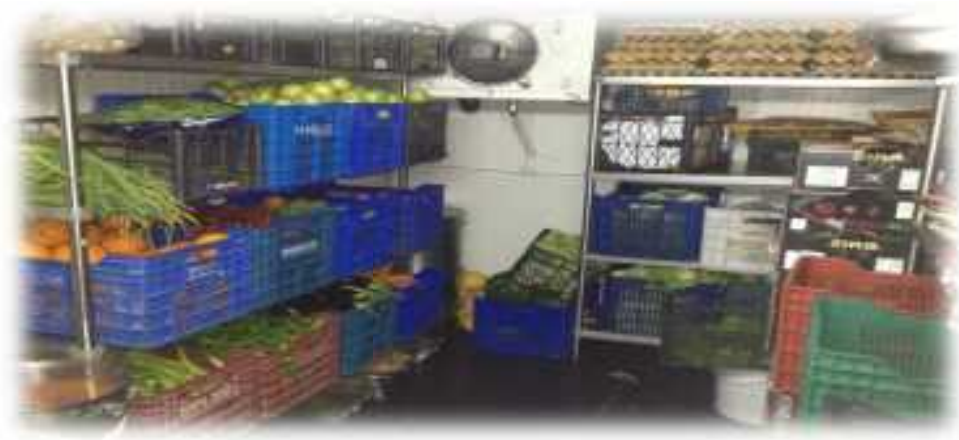

Fig. 6. Vegetables, eggs and the product to be cooked were stored together. There was no storage system, everything was stored together.

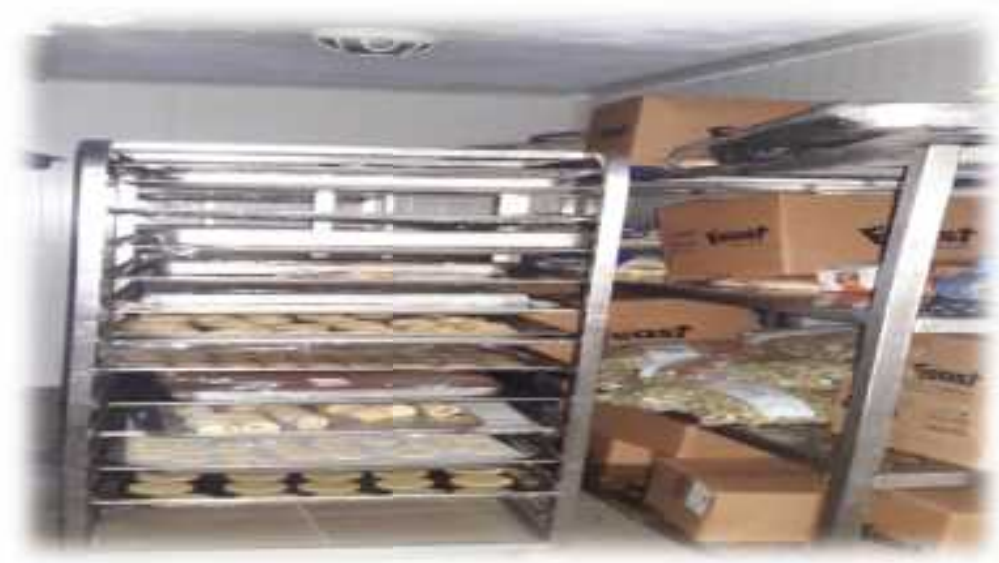

Fig. 7. There's clutter in the racks. Vegetable products and raw pastry products stored together.

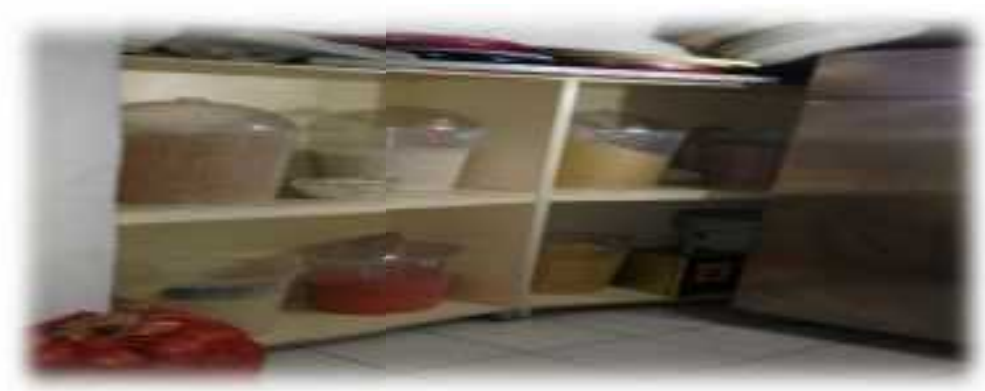

Fig. 8. This is a pastry store but there were onions, plastic caps, legumes.

$>$ Containers used were not suitable for storage. 


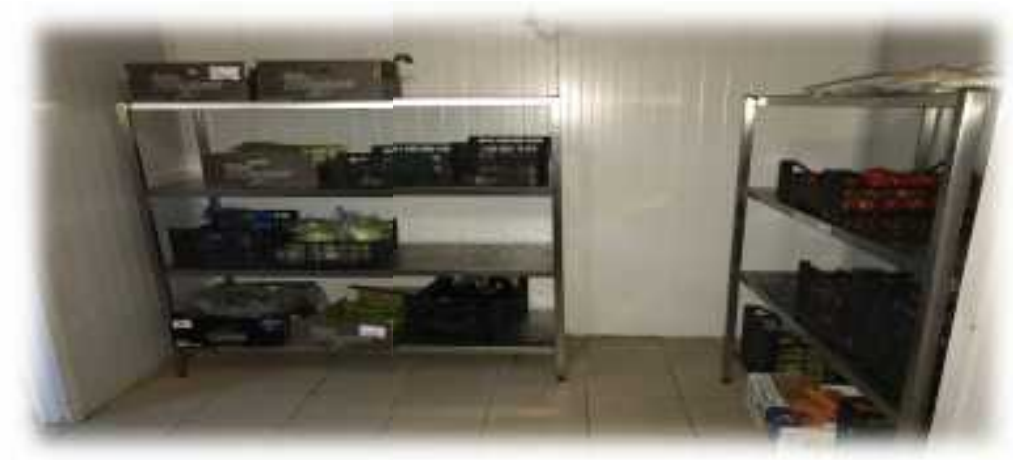

Fig. 9. Storage has been made with cardboard boxes.

Carton boxes can absorb moisture.

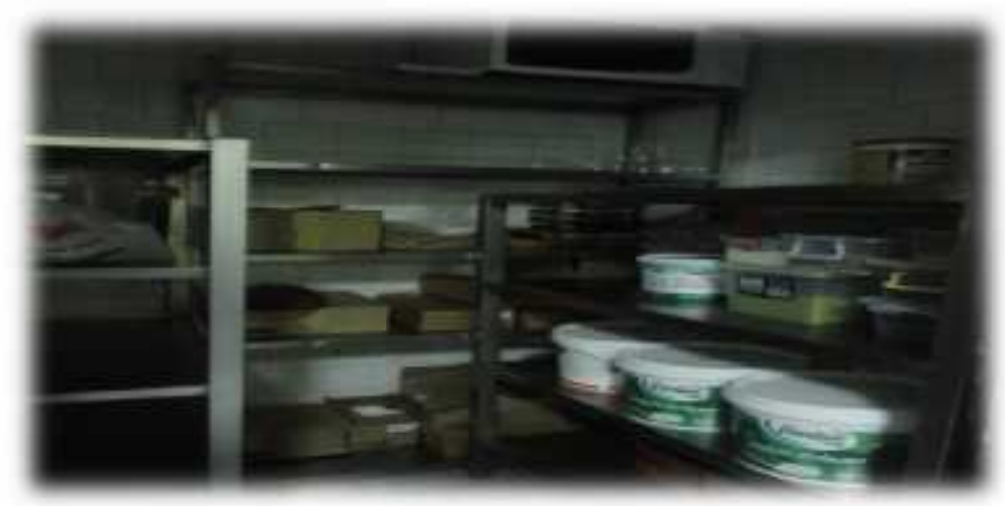

Fig. 10. Materials used in making pastries were stored in the yoghurt cabinet.

There may be food spoilage.

$>$ The foods stored were not covered.
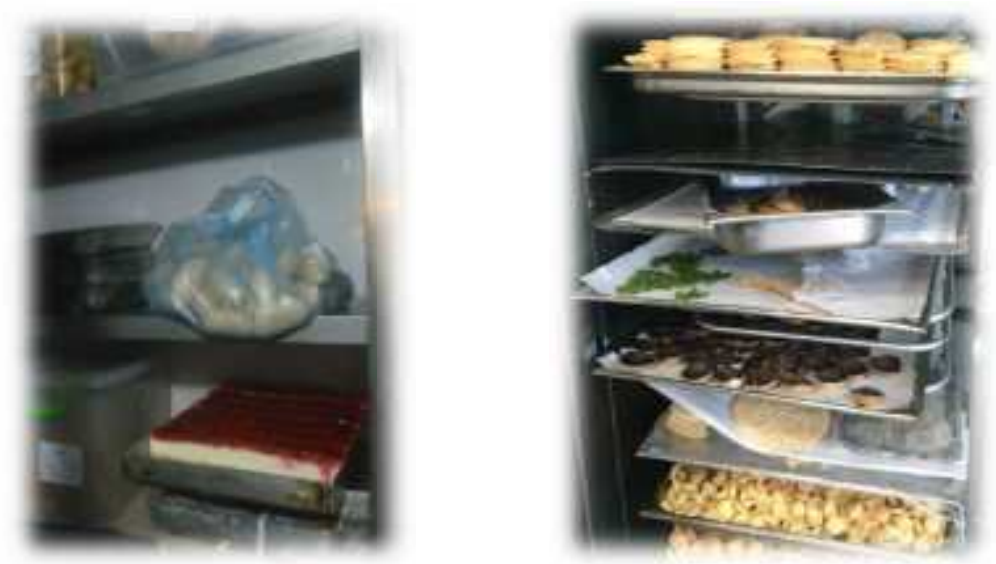

Fig. 11-12. The top of the food had been left open. there is a risk of contamination and deterioration.

$>$ Raw and cooked food was stored together. 


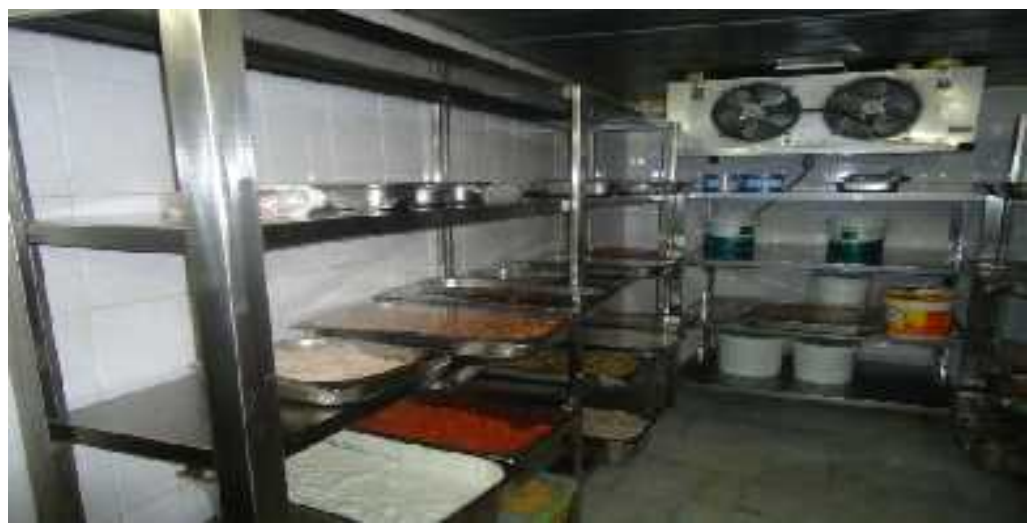

Fig. 13. Cooked meals and meats are stored together. there is a risk of contamination.

Cleaning of the storages was not taken care of.

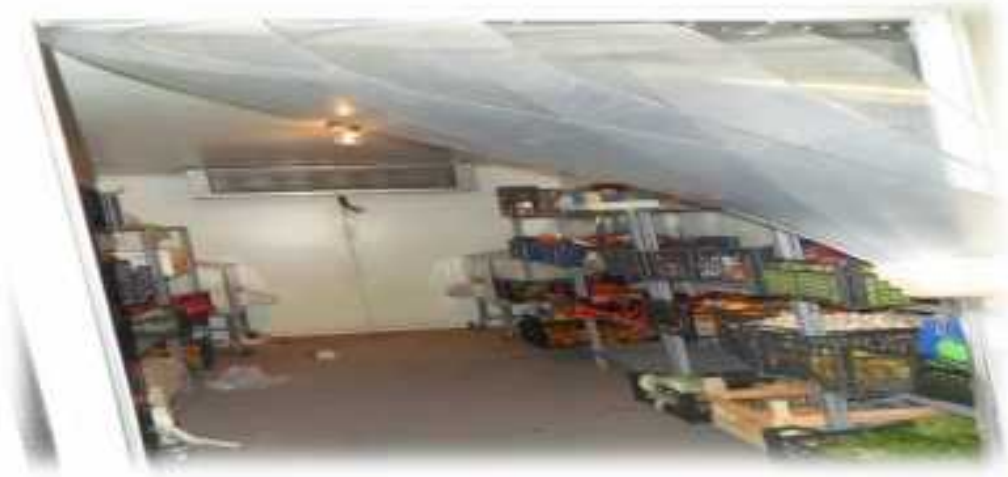

Fig. 14. Storage facilities scattered. There are food scraps in the ground.

\section{CONCLUSION AND RECOMMENDATIONS}

One of the shining stars of the service industry is the hospitality industry in which accommodation enterprises are also included. Catering divisions are the most incomegenerating part of the accommodation enterprises after room services. For this reason, the importance of kitchens where food and beverage productions are conducted in is an inevitable reality for these enterprises. The main purpose of kitchens of accommodation enterprises is to produce good quality, healthy and low-cost food. Storages are the parts of kitchens that have a significant share in producing quality, reliable and healthy food. It was determined that the accommodation enterprises involved in this study for the purpose of assessing the general conditions of the storage facilities of them are insufficient in the technical and hygienic conditions required to ensure the safe storage of the food. Storing the food in such a way as to cause contamination is an important 
threat to safe food production. The necessary physical conditions and appropriate storage of the food according to hygiene regulations should be ensured in the storage facilities of the accommodation enterprises and they should be periodically and regularly inspected to be able to provide a safe food and beverage services.

\section{REFERENCES}

1. Bulduk, S. (2003). Gıda ve Personel Hijyeni. (1. Baskl). Ankara: Detay Kitap ve Yayıncilik.

2. Erdoğan, G. (2002). Ankara'da Dört Beş Yıldızlı Otel şletmelerinde Yiyecek çecek Personelinin Eğitimi. (Yüksek Lisans Tezi). Gazi Üniversitesi Turizm şletmeciliği ve Otelcilik Eğitim Bilimleri Enstitüsü, Ankara.

3. Malhotra, N.K (1993). Marketing Research. McGrow Hill, International Edition.

4. Özdemir, B. (2001). Otel şletmelerine Mutfak Yönetimi ve Her Şey Dahil Uygulamasının Mutfak Yönetimine Etkileri Üzerine Sektörel Bir Araştırma. (Yüksek Lisans Tezi). Akdeniz Üniversitesi Sosyal Bilimler Enstitüsü, Antalya.

5. Özmen, Ö. (1994). Yiyecek Yönetiminde Temel lkeler. Eskişehir: Birlik Maatbası.

6. Saka, O. (2004). Araştırma Evreleri II: Araştırmalarda Deneklerin Seçimi. Türkiye Acil Tıp Dergisi, 4(2), 81-85.

7. http://yigm.kulturturizm.gov.tr/TR,9860/turizm-belgeli-tesisler.html 